\title{
12 Lessons from litigating for sexual and reproductive health and rights in Southern Africa
}

\author{
Tambudzai Gonese-Manjonjo and \\ Ebenezer Durojaye
}

\section{Introduction}

This chapter focuses on lessons learnt from the experiences of the Southern Africa Litigation Centre (SALC) in instituting and supporting strategic litigation on sexual and reproductive health rights in Southern Africa. Strategic litigation in this context focuses on litigation with the potential to positively impact women's sexual and reproductive health and rights(SRHR), by broadening the interpretation of the rights and working toward positive legal or other reforms in line with such interpretation. It accordingly consists not simply of the filing of a legal case, but also involves substantial research to ensure an effective outcome and sustained advocacy to support the case. Strategic litigation should lead to eventual reforms. Developing a strategy to ensure a tactical impact requires knowledge of the specific needs of women in the country, the laws and jurisprudence affecting these needs, and the extent to which litigation can have impact depending on the composition of the judiciary and the prevailing socio-political conditions in the country.

Strategic litigation has steadily gained momentum in many African countries. Some of the cases filed include challenges to violation of rights related to the right to health including sexual and reproductive health and rights. Thus, jurisprudence has emerged on issues such as maternal mortality, HIV testing, denial of life-saving medications, child marriage and adolescent sexuality. This emerging trend in social rights litigation in Africa would seem to be a positive development. While challenges remain, this development is capable of paving way for a more accountable and just society in the region. ${ }^{1}$

For strategic litigation to have an impact, there are several factors to consider:

- Does the social or societal problem have a legal issue requiring adjudication?

- Would a court be receptive to the arguments? Is the judiciary sufficiently progressive and independent?

- Would a positive judgment be implemented? Are the authorities receptive enough and are there resources?

- Is it worth it even if a positive judgment will not be implemented? 
Roa and Klugman in their useful article have identified some important considerations for a successful strategic litigation. ${ }^{2}$ These include:

- An existing rights framework - implying that the existing law in a country guarantees recognized rights for which redress can be sought.

- An independent and knowledgeable judiciary - the court is often referred to as the last hope of the masses. To effectively play this role, the judiciary must be proactive and independent from any form of interference.

- Civil society organizations with the capacity to frame social problems as rights violations and to litigate- public interest litigation is often initiated by civil society. Consequently, rights litigation will thrive in a society where the civil society groups are active, conversant with the issues and able to challenge human rights violations.

- A network to support and leverage the opportunities presented by litigation - successful social litigation requires the involvement of many stakeholders fighting for the same cause including media, health care professionals, economists and community groups.

\section{Litigation Strategy}

Having decided to litigate after this consideration, it is important to develop a litigation strategy. This will include an assessment of the jurisprudence, legal framework and litigation options in each country. Sexual and reproductive health rights are not often directly protected. Where they are, it is usually done in a restricted manner. For example, the Zimbabwean Constitution protects the right to health, inclusive of reproductive health. Yet, policies and laws more directly address issues like maternal mortality and general family planning and do not cover the broad spectrum of SRHR, including access to safe abortion. In this instance, strategic litigation might be aimed at broadening the scope of protection and promotion of sexual and reproductive rights including the provision of safe abortion.

In appropriate cases and where time and resources permit, it is beneficial to use prior research to inform possible litigation. Research, especially field research, will help in identifying the social gaps, and may indicate the possible reception by the public or respondents of any changes or developments. For example, in Malawi, after encountering a case involving the detention of pregnant learners, SALC filed a judicial review and instituted research with the Malawi Human Rights Commission on the implementation and impact of the official learner pregnancy management policy. ${ }^{3}$ The outcome of the research helped formulate a strategy for litigation. The research was necessary because it showed that most learners, and even implementers, were not aware of the official policy. Therefore, the application of the policy was arbitrary in most of the cases and dependent on the institution and implementers. The research report was used to contribute to the government review of the learner pregnancy policy. 
SALC uses a very effective method of an incremental approach to strategic litigation, using small or indirect cases to pave the way for bigger or higherimpact and more complex cases. This enables building of jurisprudence that can be used in future. Considering the often sensitive issues around SRHR, some courts take time to become receptive to certain issues and the incremental approach helps to generate gradual understanding.

Strategic ligation or social rights litigation can play an important role in advancing the rights of vulnerable or marginalized groups. It is important in providing avenues to redress human rights violations, empowering marginalized groups to obtain justice, ${ }^{4}$ serving as a means of accountability, ${ }^{5}$ serving as a catalyst for change in society, helping to create awareness on an issue and serving as a tool for social justice in society. ${ }^{6}$ Despite these positive aspects of strategic litigation, some commentators have expressed concerns about the impact of such litigation. For instance, regarding health rights litigation in Brazil, it has been argued that social rights litigation does not advance the right of the poor but tends to favour the middle class ${ }^{7}$. Others have lamented the danger of placing too much hope in litigation given the various challenges facing the court system in Africa. ${ }^{8}$

\section{Some case studies}

Valuable lessons have been learnt from the experience of litigating cases that highlight the issues around sexual and reproductive health and rights, like pregnancy, safe abortion, and how complex court procedures affect the realization of sexual and reproductive health rights. Three of SALC's cases are discussed in more detail below: The first case relates to the dismissal of pregnant women from the Lesotho Defence Force; the second relates to the provision of emergency contraceptives to rape survivors, and the third relates to prescription in medical negligence cases. Each of these cases is illustrative of the many possible ways in which strategic litigation can be developed.

\subsection{Mokhele and Others $v$ Commander, Lesotho Defence Forces and Others}

The right to decide if, when, and how to bear children is at the heart of reproductive autonomy, in line with international and regional standards. It can only be interfered with, if at all, for rational and reasonable practical considerations. International Labour Organisation (ILO) Standards have generally recognized the right of women workers to be accorded room to bear children without having to give up their careers. The standards laid out, for example, in the Maternity Protection Convention 183, ${ }^{9}$ include the right to paid maternity leave, protection from hazardous work during pregnancy, and childcare and protection from discrimination on the basis of maternity. In addition, the standards call for protection from the loss of employment due to maternity and paid maternity leave for the pregnant woman if there is need for protection of maternity in hazardous employment. This has translated, at a national level in 
the Southern African region, into the enactment of maternity protection policies, including fully or partially paid leave and protection from discrimination.

The dilemma is with balancing the right to reproduce with the practical considerations attendant with the chosen profession, especially for women in non-traditional roles and hazardous employment. This is well illustrated in a case SALC supported in Lesotho regarding reproductive rights in the military, the case of Mokhele and Others $v$ Commandere Lesotho Defence Forces and Others. ${ }^{10}$ In this case, 3 female soldiers in the Lesotho Defence Forces were dismissed from the army for falling pregnant in contravention of a Standing Order imposed by the Commander of the Lesotho Defence Forces. The Standing Order, communicated to the applicants at their passing-out parade, prohibited female soldiers of less than 5 years' service from falling pregnant, with the penalty of dismissal. The three applicants, two of whom were married and one of whom had suffered a miscarriage, were charged with violating the Standing Order. Instead of subjecting them to court martial or summary trial in line with the army regulations, the Commander dismissed them under a section of the Lesotho Defence Forces Act, which allowed the Commander to discharge members 'in the interest of the army'.

SALC supported local lawyers Phoofolo Associates and Advocate Monaheng Rasekoai in filing judicial review of the dismissals and the Standing Order in the High Court. FIDA-Lesotho supported the advocacy initiatives at the court. The applicants' arguments were both procedural and substantive, challenging the process by which they were discharged, the basis for the dismissals and the lawfulness of the Standing Order.

The applicants argued the decisions of the Commander to enact the Standing Order and discharge the applicants were contrary to public policy and common law principles of reasonableness, legality, and rationality. The charges did not raise any issues with the physical capacity of the applicants but were merely based on the non-compliance with the Standing Order. The respondents failed to consider the individual circumstances of each soldier and made blanket discriminatory assumptions that female soldiers would be negatively affected by pregnancy and birth. It was also argued that the Standing Order had a disproportionate impact on, and unduly interfered with, intimate family life and sexual and reproductive rights to choose methods and timing of family planning.

It was acknowledged that for practical considerations, there may be reason for certain restrictions but the provisions for reasonable accommodation in line with international best practice should be implemented. Reasonable accommodation would consider individual circumstances. The standard practice is to allow pregnant women to undertake modified duties, provide leave options, and enable them to return as soon as they are able. It was also argued on behalf of the applicants that the Standing Order was unlawful in that it amounted to class discrimination, because the army already has provisions for maternity leave for female soldiers in terms of the Defence Forces Act and Regulations and the Standing Order purported to arbitrarily take this right away from female soldiers of less than 5 years' service. 
The respondent argued that the army was entitled to impose whatever restrictions deemed necessary for discipline. They claimed applicants could not enjoy their rights like civilians, relying on the case of Thabang Hlapisi and Anor $v$ The Commander \& Botswana Defence Force \& 4 Others $^{11}$ and the provisions of section 24(3) of the Constitution. In justifying the Standing Order, they argued that pregnancy interfered with army discipline and the applicants' ability to be effective as army recruits, and interfered with partaking in military activities and strenuous physical activity like rolling, and combat-readiness. In addition, the Commander as 'guardian' to the recruits argued that recruits were becoming pregnant at an alarming rate and needed guidance, and thus the restriction on falling pregnant. The argument was also made that pregnancy has a negative impact on a soldier, and therefore pregnant female soldiers would no longer be effective compared to their male compatriots. Even though all of the applicants were adults and two of them were married at the time of the pregnancy, due to the possibility of contraceptive failure, the respondents argued that they should have abstained from sex as a foolproof way of preventing pregnancy. The arguments were contradictory in that the applicants were deemed to be mature enough for combat training, including handling firearms, but not mature enough to make reproductive choices.

The Lesotho Constitution prohibits discrimination based on sex (in terms of section 18) and provides for equality and equal protection of the law. The decisions of the respondents and the effects of the Standing Order could ordinarily have been challenged as breaches to the Bill of Rights. However, the provisions of section 24(3) allow for the limitation of most of the Bill of Rights by military law, rendering it difficult to file a direct constitutional challenge. It was therefore decided to file judicial review based on the usual grounds of lawfulness, rationality, and reasonableness. It was argued that decisions that amount to unfair discrimination, and decisions made for improper purposes are included in the definition or consideration of the unreasonableness of administrative action. Amongst the principles of state policy in the Lesotho Constitution are the values of equality, non-discrimination and justice and just and favourable work conditions, including maternity protection.

In reviewing the reasonableness of the Commander's decisions, the lawfulness of the Standing Order itself, and the decision to discharge the applicants, the Court made very progressive findings on women's reproductive rights. The Court held that by virtue of the provisions of international instruments like CEDAW and the 2000 International Labour Organisation(ILO) Maternity Protection Convention, ${ }^{12}$ women in the army were entitled, like other women, to the rights enshrined therein, and that the army, like every other entity, had the duty to ensure that their rights were protected. The Standing Order was held to be ultra vires the enabling legislation (the Defence Forces Act and Regulations), which did not prescribe pregnancy as a ground for discharge. The Court held the Commander could not make regulations which had the effect of disenfranchising a whole section of the army. This was the province of parliament. The Court also found that there was no basis 
for differentiating between women recruits and women who were entitled to maternity leave in the army. Therefore, the court found that the Commander's decisions in enacting the Standing order and instituting the process of discharge of the applicants were arbitrary and irrational. The Court cited with approval the cases presented by the applicants, like the United States case of Crawford $v$ Cushman ${ }^{13}$ in which it was held that the policy of discharging pregnant women violated their right to due process under the 5th Amendment because it created an irrebuttable presumption that a pregnant woman would be permanently unfit for duty, despite the fact that pregnancy is temporary and not a permanent disability. The Court stated:

The contention by the Commander that pregnant soldiers must be discharged because they compromise the army's operational capacity and jeopardize military discipline is not only an argument in torrorem populi but a throw-back to the patriarchal view that pregnant women are not fit to work and, therefore, are a disposable workforce. The view that soldiers need permission to be pregnant — which permission is obtainable after five years' service - is merely mentioned to be rejected. ${ }^{14}$

In agreement with the decision of the European Court of Justice in Brown $v$ Rentokil, ${ }^{15}$ the court also decided that dismissal on account of pregnancy is direct discrimination on the grounds of sex, because pregnancy is a condition that affects only women. The Court aptly characterizes the true nature of the case thus:

This case is, therefore, about the applicability and observance of the values espoused by these international instruments in relation to the laws governing military service in the Kingdom. Although, in form the case is about the legality of the decision of the Commander of the Lesotho Defence Force to discharge pregnant soldiers, it is in substance a challenge to the culture of patriarchy in the military and an assertion of sexual and reproductive rights in military service. What is being contested is the idea that female soldiers are incapable to bear arms and babies at the same time and, on that account, are not fit for military purpose. ${ }^{16}$

Despite the worldwide existence of maternity protection in line with ILO standards, the international and regional standards laid out in CEDAW, and the Maputo Protocol, maternity protection does not always amount to proper recognition of women's rights to reproductive choices, especially in the interpretation of the courts. The Lesotho judgment is a good example in this respect. A recent South African Labour Court case regarding maternity protection restrictions in hazardous employment environment, however, achieved the opposite result. ${ }^{17}$

The conflicting results in the above two cases show the difficulties in litigating for reproductive rights in the context of employment and disciplinary or 
hazardous contexts, where traditional patriarchal norms in the guise of practical or health concerns limit women's autonomy. The way these practical or health concerns are handled betray the underlying disregard for the rights of women. Nonetheless, it is encouraging that the courts are beginning to liberalize and dismantle the patriarchal system.

\subsection{Mapingure v Minister of Home Affairs and Others}

SALC provided some technical support to Zimbabwe Women Lawyers Association (ZWLA) on the Zimbabwean case of Mapingure $v$ Minister of Home Affairs \& Others. ${ }^{18}$ The case illustrates the courts' treatment of reproductive autonomy in the context of the right to safe abortion. Abortion is only legal under limited circumstances in Zimbabwe, including in cases where the pregnancy is the result of rape or incest, or where it poses a danger to the life or physical health of the woman.

Zimbabwe is a state party to and has ratified the Convention on the Elimination of All forms of Discrimination Against Women (CEDAW). Article 12 of CEDAW mandates member states to eliminate discrimination against women in healthcare and to ensure equal access to health services, including reproductive health services. In terms of General Recommendation 24 of the CEDAW Committee on Article 12, it is discriminatory for a state to refuse legal provision of reproductive health services for women. ${ }^{19}$ In the case of conscientious objection to the performance of such services, an alternative for their provision should be made. To respect, protect, and fulfil women's rights to equal access to health services, states are mandated to ensure this is achieved through legislation, policy executive action, and an effective judicial system. States are also urged to respect women's right to access healthcare by not putting up barriers through means of obstructive laws that impact services only sought or needed by women, including criminalization and punishment. ${ }^{20}$

The obligation to protect women's rights to healthcare entails enacting laws and policies binding on public and private entities, like hospitals, to address violence against women and the provision of appropriate healthcare. Although CEDAW does not explicitly refer to the right to safe abortion as part of states' obligations to ensure equal access to health care by women, this is implicit in the reference to services that are specifically needed by women.

In the case of $L C v$ Peru, ${ }^{21}$ decided by the CEDAW Committee, a 13-yearold girl was denied an abortion after falling pregnant because of sexual abuse. She became permanently disabled from the lack of timely treatment after suffering serious injuries from a suicide attempt. This took place even though the Peruvian Penal Code allowed for access to abortion where the pregnancy posed a danger to her health. She brought a Communication before the CEDAW Committee and alleged violation of her right to health, dignity, and freedom from discrimination in the access of health services. The CEDAW Committee interpreted General Recommendation 24 in this case, stating the denial by the state hospital of an abortion and the requisite emergency services constituted 
discrimination. It also found that, although LC was entitled to a legal abortion in terms of the Peruvian Penal Code, the state legal and health systems had failed in implementation to realize the rights conferred by the law. Therefore, the state had failed to establish legal protection of women's rights as envisaged in Articles 2(c) and 2(f).

Zimbabwe, as a state party to CEDAW is obliged to protect, promote, and fulfil the rights of women to healthcare services. By implication, Zimbabwe is mandated to provide safe abortion where it is required, specifically by the effective implementation of laws that allow for access to safe abortion. The CEDAW Committee's Concluding Observations in 2012 made recommendations to Zimbabwe to liberalize its abortion laws, decriminalize, and ensure access to safe abortion by simplifying the procedures required to access it. ${ }^{22}$

The Protocol to the African Charter on Human and Peoples' Rights on the Rights of Women (Maputo Protocol) in its Article 14(1) defines the rights of women to health and reproductive health, including the right to control their own fertility, to make free decisions on child rearing and child spacing, to have family planning education, and to make choices of contraception. Article 14(2) directly specifies measures to be taken by states to realize the rights in Article $14(1)$, which includes access to safe abortion as one of the requisite measures. It can be argued that in specifying legal abortion on limited grounds, Article $14(2)$ (c) limits the rights conferred in Article 14(1). However, the explicit mention of the right to access safe abortion in the Protocol is a progressive move and imposes a peremptory obligation on member states to provide for safe abortion. The African Commission on Human and Peoples' Rights has elaborated on the provision of Article 14 (2) (c) explaining that states are obligated to remove all barriers to safe abortion services for women. ${ }^{23}$ According to Ngwena, ${ }^{24}$ this elevates the right to access safe abortion as a recognized human right, which imposes obligations on member states.

Mapingure's case illustrates the extent to which safe abortion is available where it is legally permissible, and to what extent the international obligations of Zimbabwe are achieved. This was a case challenging the government's failure to provide emergency contraception to prevent pregnancy and its subsequent failure to assist in procuring a legal abortion after rape.

The applicant in the matter was gang-raped at her house and promptly sought assistance from the doctor who treated her, for emergency contraceptives to prevent pregnancy. The doctor declined to assist without a formal police report, which the police delayed in supplying until the crucial 72-hour period expired. She had already fallen pregnant by this time. After discovering the pregnancy, the applicant approached a prosecutor for advice and assistance in obtaining a lawful abortion, provided for in terms of the law. She was erroneously advised that she had to wait for the criminal case to be completed before she could be issued with the Magistrate's certificate. By the time she obtained the certificate, the pregnancy was at an advanced stage and the medical professionals declined to perform the abortion, judging it unsafe. 
She issued summons against the Ministry of Home Affairs (for the police), the Ministry of Health and Child Welfare (in charge of doctors), and the Ministry of Justice Legal and Parliamentary Affairs (in charge of the courts) for breach of their duty of care in failing to prevent the pregnancy and in failing to provide a lawful abortion. She sought damages occasioned from the physical and mental anguish caused by the respondents' negligence and breach of their duty of care. She further characterized the case as a wrongful pregnancy and birth issue ${ }^{25}$ and sought damages for the financial and psychological costs of having and raising the child.

The High Court dismissed the claim on the grounds that the respondents' duties of care towards the applicant did not extend to the termination of pregnancy outside any stated obligations in the Termination of Pregnancy Act. The Court stated that the Police, although admittedly negligent in their dilatoriness in rendering assistance to the applicant, could only be considered to have been 'negligent in the air', and thus attracted no liability. The Court also stated that the doctor had no obligation to terminate the pregnancy in the absence of authorization in the form of a certificate from a Magistrate in terms of the law. This was despite the fact that emergency contraception administered within 72 hours of the sexual assault would have prevented, not terminated, the pregnancy, and therefore would not have needed an authorization. The doctor and, apparently, the Court were clearly mistaken about the law and facts in this instance. In dismissing the claim against the court officials who had given erroneous advice, the Court held that the laws were clear that it was the applicant's duty to take steps to obtain the requisite authorization. Therefore, the fact of erroneous advice from the court officials did not raise liability because they 'were not her legal representatives'. The Court found that the applicant's predicament was caused by her own ignorance of the procedures she had to follow, and therefore her ignorance of the law could not be an excuse to find the respondents liable.

On appeal, the Supreme Court found the state (the Police and the Ministry of Health) liable for failure to facilitate and provide emergency contraceptives to prevent the pregnancy. However, the Court found the state was not liable for failure to provide a legal abortion, as the Court decided that the responsibility to procure the abortion lay on the applicant. The basis upon which the court found the Police and the doctor liable was that the police's duty of care extended beyond their statutory duties to arrest and investigate crime, and the doctor's duty of care extended beyond his duties to administer the emergency contraceptive drug or to advise her where to get it, even though the drug was apparently obtainable over the counter in pharmacies. Their failure to exercise this extended duty of care resulted in harm to the Appellant, for which they were liable.

It is not clear why the court officials could not be held to the same standard as the police and be found liable for failure by the appellant to obtain a lawful abortion, especially since they volunteered wrong legal advice, which the Appellant probably relied upon, causing the delay. Feltoe ${ }^{26}$ argues that once 
the court officials had volunteered legal advice, they put themselves within the ambit of a duty of care towards the Appellant. Further, there might have been a basis for liability if the trial court had called for evidence or the Supreme Court remitted the matter for more evidence to the High court. The Supreme Court held the provisions of the Termination of Pregnancy Act meant that it was the Appellant who had a duty to take measures to obtain the certificate, which included filing an affidavit with a magistrate detailing the grounds for termination.

The Supreme Court in its judgment referenced international norms derived from CEDAW (particularly Article 16, on the right for women to decide on the number and spacing of children and to have adequate access to information in exercising those rights), and the United Nations Declaration on the Elimination of Violence against Women 1993 regarding the duty of states to ensure elimination of violence against women by providing effective redress mechanisms. It also referred to the rights and imperatives in Article 4 of the Maputo Protocol, which require states to establish effective information and reparation systems for women victims of violence; Article 14(1) on reproductive rights; and Article 14(2)(c) on access to safe abortion. This was from the arguments raised by the Appellant. The Court found these international instruments should have persuasive value in the interpretation of statutes and the common law, although not formally binding because of non-domestication. However, as far as the Court was concerned, the extent to which these norms were relevant was in the state enacting laws to enable termination of pregnancy where appropriate and providing the necessary information and facilities within the available state resources. It did not extend to a duty to initiate Court proceedings on behalf of the victim.

The Court found, however, in passing, that the law as written was unclear in the required steps to be taken by a victim of rape who requires termination and the relevant duties of state actors in the process. The Court stated that, to bring the state in compliance with its international obligations, it must amend the law to ensure effective assistance to rape victims. This is an admission by the Court of the ineffectiveness of redress mechanisms put in place through legislation.

The Court decision on abortion is illustrative of the limitations to women's access to abortion occasioned by conservative application of the law. The Court fails to affirm a women's right to safe abortion and the obligations of the state, including the judiciary, to uphold this right as recognized in legislation. In addition, the new Zimbabwe Constitution of 2013 had already been passed when the matter was argued, with provisions on the right to health. The provision of the Constitution on the right to health ought to have been considered by the Court in this case. Section 76 of the Constitution provides for the right to basic healthcare services, including reproductive healthcare, and requires the state to put in place measures for the progressive realization of the right. When the provisions of the constitution are read together with the provisions of Article 14 of the Maputo Protocol, the right to safe abortion 
is therefore constitutionally guaranteed. A provision in section 48 , however, limits this right by restricting abortion through the protection of the life of the unborn child. Abortion is only allowed in terms of the provisions of an Act of Parliament. ${ }^{27}$

The Court completely overlooked the provisions of the Constitution in its interpretation of the Termination of Pregnancy Act in the context of the acts complained of and the right of access to reproductive healthcare. This is despite that in terms of section 46(2), the Court is supposed to be guided by the spirit and objectives of the Bill of Rights in its interpretation of legislature. Some of the relevant human rights contained in the Bill of Rights which the court should have applied include the right to bodily and psychological integrity, ${ }^{28}$ which encompasses the right to make reproductive choices, the right to equal protection of the law, and non-discrimination on the basis of sex and gender ${ }^{29}$ in addition to health rights. In this case, the court found problems with the law but declined to take up the challenge.

This submission is made mindful of the fact that the case had not been brought on a Constitutional basis, but in delict. This, of course, made it difficult to make constitutional arguments or have the court make constitutional findings. However, the Court is empowered in terms of section 176 of the Constitution to develop the common law in line with justice and the constitution, which it could have done on its own. For example, the High Court in the case of $S v \mathrm{Jeri}^{30}$ applied constitutional imperatives in a murder case where a woman had been killed because she had rejected the sexual advances of the man accused. In convicting the accused, the court concentrated on the genderbased violence dimensions of the offence and the constitutional provisions that militate against it. The Court applied the provisions of sections 51(right to dignity) and 52(b) (right to freedom from violence) to contextualize the duties of the court in assessing the facts relating to the motivations, given the defences to the killing. The Court determined the accused had violated the deceased's rights. The Court said:

As courts, it is our duty to be alive to the constitutional imperatives and to make the gender connections from the everyday cases that we deal with. The motivations for the assault were clearly gendered and to fail to speak to the gender dimensions of this case would be to legitimise genderbased violence within the criminal justice system. Our efficacy as courts in addressing gender-based violence rests in ensuring that the criminal justice system speaks to the lived realities and experiences of all its victims. ${ }^{31}$

According to Feltoe, ${ }^{32}$ the Jeri judgment is a good example of how the courts should approach cases involving violence against women:

The judgment in the Jeri case shows how the courts should approach cases involving gender-based violence. The courts have an obligation to base their judgments in such matters squarely on the constitutional provisions 
on the rights of women. They need to make it quite clear that violent behaviour arising from erroneous male misconceptions and prejudices about their right to dominate women will be severely dealt with.

It is possible that the court in the Mapingure case might have made different conclusions had the matter been brought as a constitutional challenge under the provisions of the new constitution. However, when the case was initially filed in 2007, the Zimbabwe Constitution, 1979 did not contain health rights or some of the other progressive rights present in the new Constitution. It could have been possible to bring a claim alleging discrimination based on sex, but without guarantee of success. The major complication with cases of this nature is that they are often delictual and subject to rigid common law principles that are often difficult to discharge. With the new Constitution, it is hoped that a new kind of jurisprudence relating to the direct protection of rights, including sexual and reproductive rights, will emerge in Zimbabwe and ensure justice for women.

Nevertheless, the judgment as it stands affords some relief to victims of sexual violence with regards to the duties of the police and other officers with a direct duty of care. Another positive aspect of the judgment was the court's acknowledgment of the lack of clarity in the law, bringing attention to the need for law reform and giving room to advocacy. This effectively leaves room for future development.

The applicant was subsequently awarded damages against the police and health ministry. Despite this positive outcome at court in this matter, the applicant took years to receive payment from the state. This highlights the need for persistent follow-through and advocacy at the domestic level to the point of implementation to ensure that, in addition to the greater good coming out of a precedent-setting judgment, the individual on whom the case is predicated actually receives remedies.

\subsection{GMJ v Attorney General of Botswana}

Many countries in Southern Africa do not have stand-alone mechanisms for the protection of sexual and reproductive health rights. In seeking redress for violations of sexual and reproductive rights, women must turn to the civil litigation system and, more commonly, file medical professional negligence claims. In addition to the complexities of the medical field which many marginalized and vulnerable women have little knowledge about, women have to contend with navigating the rather tenuous road of legal and court procedures.

The complexities often lead to failure to access justice and redress for violations of sexual and reproductive health. One common barrier to the effective vindication of women's rights in this area is the concept of extinctive prescription. This is the concept that, due to the passing of time, certain rights either become extinguished or are no longer enforceable. Prescription is often set 
out in national legislation, providing for specific periods within which certain rights can be vindicated. After the specified period passes, the rights become unenforceable or are extinguished.

The case of GMJ $v$ Attorney General, ${ }^{33}$ decided in the Botswana Court of Appeal on 26 October 2018, illustrates how the laws of prescription act to limit access to redress for sexual and reproductive health violations for women, and how court decisions can be used to clarify and simplify the requirements of access.

The appellant (GMJ) had undergone a surgical procedure for removal of the womb resulting in severe complications which completely disrupted her life and physical and mental well-being. She issued summons against the Respondent, claiming damages for medical negligence and lack of proper postoperative care. The Respondent filed a special plea of prescription on the grounds that the claim had prescribed. The Respondent argued the claim was filed after 3 years from the date of the cause of action, when the plaintiff first noticed symptoms and became aware of the injury. In terms of the Botswana Prescription Act, ${ }^{34}$ a claim for damages prescribes after 3 years from the date of knowledge of the injury giving rise to the claim. The question to be answered was the time a person would be considered to have knowledge of the injury, or the facts giving rise to the claim. The High Court agreed with the State and decided she obtained knowledge of the facts giving rise to the claim the moment GMJ experienced the symptoms of her problem, and therefore the claim had prescribed.

GMJ filed an appeal with the Botswana Appeals Court and argued the point of knowledge of the facts giving rise to her claim could not have been the point when she became aware of the symptoms she had, in line with decided South African cases and based on similar prescription provisions. ${ }^{35}$ The South African Constitutional Court in Links $v$ Member of the Executive Council, Department of Health, Northern Cape Province ${ }^{36}$ held that in cases involving medical professional negligence, the party relying on prescription has the duty to show that the plaintiff had enough facts to cause them to conclude there was fault on the part of the medical staff that caused their injury. The Court said:

It seems to me that it would be unrealistic for the law to expect a litigant who has no knowledge of medicine to have knowledge of what caused his condition without having first had an opportunity of consulting a relevant medical professional or specialist for advice. That in turn requires that the litigant is in possession of sufficient facts to cause a reasonable person to suspect that something has gone wrong and to seek advice. ${ }^{37}$

The Botswana Court of Appeal issued a judgment in favour of GMJ and reinstated her claim. The Court ruled that the suspicion of the cause of the Appellant's injury was insufficient to constitute knowledge because she did not know for a fact what had caused the symptoms, and ruled the knowledge of 
the cause of her condition was a material fact for the purpose of determining who was at fault. Thus, the relevant date for the purposes of prescription was not the date she noticed the symptoms, but the date she became aware of the cause for the symptoms.

Although the decision was solely grounded in the law of delict and concerned civil law and procedure, the decision is very significant in the realization of women's sexual and reproductive health and rights when it comes to accessing justice. In line with CEDAW Committee General Recommendation 24 on Article 12 of CEDAW, Botswana is obligated to respect, protect and fulfil women's right to reproductive health services through effective legislation, policy, implementation and judicial action. This judgment is a step towards this obligation.

Many women who have experienced violations, such as coerced or forced sterilization and other reproductive rights violations, are unable to obtain redress because of prescription, whether due to the lack of medical or other technical knowledge, the lack of access to legal advice, or personal circumstances. This case is an important step towards the realization of effective redress for violations, but it is only a start. A total elimination of prescription laws when it comes to violations of women's rights would be the ultimate victory, either through constitutional interpretation or the creation of a totally different cause of action based on the rights afforded through international and national laws.

\section{Challenges}

From the cases discussed above and other experiences, the results of strategic litigation can be rewarding, but are not without challenges, both general, content-specific, and dependent on geographical location. Litigation takes time, and delays in the conclusion of cases from the judicial system, state responses, and handing down judgments are common. The delays are less of an issue in some countries than others. Mapingure's case was initially filed in 2007 and the Supreme Court judgment was only issued 7 years later, in 2014. However, judgments are handed down quickly in other countries like Botswana.

A major challenge to instituting strategic litigation is often associated prohibitive costs, including lawyer fees, engagement of experts, court and messenger/sheriff $\operatorname{costs}^{38}$. In addition, the risk of getting an adverse costs order in the event of an unsuccessful suit is daunting and may affect the decision to litigate in uncertain cases. In some cases, it may be possible to convince the Court not to award costs, especially in cases with important constitutional or national interest value. The High Court in Mapingure dismissed the claim but declined to award costs against her because of the national importance of the case. GMJ, however, had to deposit security for costs for the appeal and was in danger of having an adverse costs order against her, had she not succeeded in the case.

The implementation of judgments sometimes depends on State goodwill or resources. In many jurisdictions, judgments cannot be enforced in the traditional ways and clients may not ultimately get the actual relief granted by the 
Court. For example, when the applicant in the Mapingure case in Zimbabwe was awarded damages by the Court she was not paid for a long time. She could not issue out process to attach State property to satisfy the award. Effectively, changes in law/policy can be of limited benefit for women.

There are often difficulties in mobilizing affected clients to attend court or in maintaining the client's involvement and interest, due to fear of stigmatization and inadequate information. These difficulties also include lack of personal resources to attend court and the unavailability of adequate funding. A major issue affecting the efficacy of strategic SRHR litigation is general ignorance and negative attitudes towards SRHR by the public and courts. ${ }^{39}$ In addition, as illustrated above, prescription laws are often an issue in SRHR cases where it is intended to sue for damages or litigate against the State.

Most importantly, the nature of cases relating to sexual and reproductive health and rights can be very traumatic to clients. The cases often relate to distressing experiences which continue to have a significant impact on their lives. They also relate to very personal issues which create additional stress relating to how such issue will be perceived in court and in the public domain. It is thus essential to provide clients with psycho-social support throughout the litigation process.

\section{Lessons Learnt}

It is important to explore ways in which some of the challenges outlined above can be mitigated. It helps to ensure that local lawyers and partner organizations maintain regular communication with clients, and to ensure that all decisions relating to the case are made with client's consent and best interest.

Collaboration is also a very strong tool in effective strategic litigation, as social movements identify cases and sustain advocacy. Sustained advocacy around the case is essential at the hearing and after judgment. Sustained advocacy ensures the case becomes a catalyst for similar cases in other countries and ensures the value of judgments for continued advocacy; litigation cannot always provide redress to all.

For efficiency, there should be thorough research of submissions to present the best arguments that will enable the judge to write judgments without fear of negative repercussions. The research of submissions should also ensure sufficient evidence is obtained, including expert evidence to support technical arguments around health and SRHR.

Where possible, it is also important to choose the best clients for strategic litigation and protect their privacy by obtaining confidentiality orders in advance where necessary. The use of confidentiality orders is an important factor in ensuring that vulnerable clients can co-operate without fear of stigma or other negative repercussions. It is also important to utilize complaints mechanisms and other non-litigious measures before proceeding to institute litigation. Litigation should be used as a last resort. 


\section{Conclusion}

Strategic litigation is a very effective tool for reform, especially by highlighting the gaps in the law and the effect of the gaps on the lived realities of women's lives. It also serves as an important means of holding states accountable to realize SRHR. Nevertheless, strategic litigation can be challenging, especially considering differing interpretations and unwillingness of some courts to embrace international norms that promote sexual and reproductive rights. The value of the major role of the law in social change and cohesion cannot be overlooked, however, and it is important to have an integrated approach with litigation, advocacy, and other non-litigious means to achieve social change.

\section{Notes}

1 E Durojaye Litigating the right to health in Africa: Challenges and prospects (2016).

2 M Roa \& B Klugman 'Considering strategic litigation as an advocacy tool: A case study of the defence of reproductive rights in Colombia' (2014) 44 Reproductive Health Matters 31-41.

3 SALC \& MHRC Towards a human rights-based approach to learner pregnancy management in Malawi (2017) http://www.southernafricalitigationcentre.org/2017/07/31/salcresearch-report-towards-a-human-rights-based-approach -to-learner-pregnancy-management-in-malawi (accessed 16 October 2020).

4 E Durojaye 'Relevance of health rights litigation in Africa' in E Durojaye (ed) Litigating the right to health in Africa: Challenges and prospect (2016) 3.

5 S Gloppen 'Litigating as a strategy to hold governments accountable for implementing the right to health' (2008) 10 Health and Human Rights 21.

6 M Pieterse 'The potential of socio-economic rights litigation for the achievement of social justice: Considering the example of access to medical care in South African prisons' (2006) 50 Journal of African Law 118.

7 O Ferraz 'Harming the poor through social rights litigation: Lessons from Brazil' (2011) Texas Law Review 1643; see also, G Rosenberg The hollow hope: Can courts bring about social change? (2008).

8 A Yamin \& S Gloppen Litigating health rights: Can courts bring more justice to health? (2011).

9 ILC (2000)

10 Mokhele and Others $v$ Commander, Lesotho Defence Force and Others (CIV/APN/442/16) [2018] LSHC 2 (14 February 2018).

11 MAHGB-000301.

12 C183 - Maternity Protection Convention, 2000 (No. 183).

13531 F.2d 1114(2d Cir.1976).

14 See para 12 of judgment.

15 C-394/96.

16 See para 23 of judgment.

17 Tshegofatso Manyetsa v New Kleinfontein Gold Mine (Pty) Ltd www.safli.org/za/cases/ ZALCJHB/2017/404

18 (2014), Judgment No. SC 22/14, Civil Appeal No. SC 406/12.

19 CEDAW Committee General Recommendation 24 on women and health para 9.

20 As above.

21 LC v Peru, Communication 22/2009, CEDAW/C/50/D/22/2009 (2011).

22 See CEDAW Committee Concluding observations to Zimbabwe CEDAW/C/ZWE/ CO/2-5, 23 March 2012. 


\section{Tambudzai Gonese-Manjonjo and Ebenezer Durojaye}

23 General Comment No. 2 on Article 14.1 (a), (b), (c) and (f) and Article 14.2 (a) and (c) of the Protocol to the African Charter on Human and Peoples' Rights on the Rights of Women in Africa adopted by the African Commission on Human and Peoples' Rights during its 54th Ordinary Session in November 2014.

24 C Ngwena 'Inscribing abortion as a human right: Significance of the Protocol on the Rights of Women in Africa' 32 (2010) Human Rights Quarterly 810.

25 Defined by N Liu 'Wrongful life: Some of the problems' (1987) 13 Glasgow University Journal of Medical Ethics 69-73 as claims consisting of parents alleging that, had the defendant not been negligent, they would either have avoided conception or terminated the pregnancy.

26 G Feltoe 'Case note on the case of Mapingure v Minister of Home Affairs E Ors S-22-14 2017’ Zimbabwe Electronic Law Journal 1.

27 Section 48(3) states that abortion may be allowed in terms of an Act of Parliament that protects the life of an unborn child.

28 Section 52.

29 Section 56.

30 HH 516/17.

31 As above.

32 As above.

33 CVHGB-003267-15 http://www.southernafricalitigationcentre.org/2018/06/15/botswanachallenging- prescription-in-medical-negligence-claim/ (accessed 20 October 2020).

34 Section 4(2)(iv) as read with section 6(1)(a)(1).

35 McLeod $v$ Kweyiwa 2013 ZASCA 28, Sibiya $v$ the Premier of the Province of KwaZulu Natal 2008(1)All SA 295, Links v Member of the Executive Council, Department of Health, Northern Cape Province. [2016]ZACC 10

36 Links $v$ Member of the Executive Council, Department of Health, Northern Cape Province. [2016]ZACC 10

37 As above para 47

38 Durojaye (n 1$) 5$.

39 See J Odikpo \& E Durojaye 'Litigating health rights issues: The Nigerian experience' in E Durojaye (ed) Litigating the right to health in Africa: Challenges and prospect (2016) 141; E Durojaye 'Litigating the right to health in Nigeria' in M Kilander (ed) International law and domestic human rights litigation (2010) 149.

\section{References}

Baxter, L Administrative law (Juta Cape Town 1984).

Bradley, A \& Ewing, K Constitutional and administrative law (Routledge 2015).

Durojaye, E (eds) Litigating the right to health in Africa: Challenges and prospects (Routledge 2016).

Durojaye, E 'Litigating the right to health in Nigeria' in Kilander, M (ed) International law and domestic human rights litigation (Pretoria University Law Press 2010) 149.

Durojaye, E 'Relevance of health rights litigation in Africa' in Durojaye, E (ed) Litigating the right to health in Africa: Challenges and prospects (Routledge 2016) 1.

Feltoe, G 'Case note on the case of Mapingure v Minister of Home Affairs \& Ors SC-22-14' [2017] Zimbabwe Electronic Law Journal 01.

Feltoe, $\mathrm{G}$ 'The role of the criminal law in the protection of women against gender-based violence: Case note on S v Jeri HH 516-17’ [2017] Zimbabwe Electronic Law Journal 03.

Ferraz, O 'Harming the poor through social rights litigation: Lessons from Brazil' [2011] Texas Law Review 1643. 
Gloppen, S 'Litigating as a strategy to hold governments accountable for implementing the right to health' (2008) 10 Health and Human Rights 21.

Kilander, M (eds) International law and domestic human rights litigation (Pretoria University Law Press 2010)

Liu, N 'Wrongful life: Some of the problems' (1987) 13 Glasgow University Journal of Medical Ethics 69.

Ngwena, C 'Inscribing abortion as a human right: Significance of the protocol on the rights of women in Africa' [2010] Human Rights Quarterly 32.

Odikpo, J \& Durojaye, E 'Litigating health rights issues: The Nigerian experience' in Durojaye, E (ed) Litigating the right to health in Africa: Challenges and prospects (Routledge 2016) 141.

Pieterse, L 'The potential of socio-economic rights litigation for the achievement of social justice: Considering the example of access to medical care in South African prisons' (2006) 50 Journal of African Law 118.

Roa, M \& Klugman, B 'Considering strategic litigation as an advocacy tool: A case study of the defence of reproductive rights in Colombia (2014) 44 Reproductive Health Matters 31.

Rosenberg, G The hollow hope: Can courts bring about social change? (2 ed) (University of Chicago Press 2008)

SALC \& MHRC Towards a human rights-based approach to learner pregnancy management in Malawi (Pretoria University 2017) http://www.southernafricalitigationcentre.org /2017/07/31/salc-research-report-towards-a-human-rights-based-approach-to-learner -pregnancy-management-in-Malawi (accessed 16 October 2020).

Yamin, A \& Gloppen, S (eds) Litigating health rights: Can courts bring more justice to health? (Harvard University Press 2011). 